\title{
PENGARUH PENGGUNAAN MEDIA SOSIAL TERHADAP PENGEMBANGAN USAHA KECIL MENENGAH (UKM) \\ Elvina
}

Sekolah Tinggi Ilmu Ekonomi Labuhanbatu, Sumatera Utara - Indonesia

E-mail : Elvinahrp18@gmail.com

\begin{abstract}
Abstrak
Studi ini bertujuan untuk mengetahui pengaruh implementasi media sosial terhadap perkembangan usaha kecil menengah (UKM), pengaruh media sosial terhadap peningkatan pemasaran UKM, dan pengaruh media sosial terhadap peningkatan produktivitas UKM. Studi ini menggunakan metode wawancara terstruktur, wawancara mendalam dan observasi terhadap UKM dan media sosial yang digunakan. Subyek dalam penelitian ini adalah pemilik, pengelola dan karyawan UKM yang dipilih secara purpose sampling. Studi ini menyimpulkan bahwa UKM yang diobservasi telah menggunakan media sosial dalam perusahaannya. Media sosial yang paling banyak digunakan adalah Facebook, Twitter dan Instagram
\end{abstract}

Kata kunci : media sosial, pemasaran, produktivitas, UKM

\section{A. PENDAHULUAN}

\section{Latar Belakang Masalah}

Salah satu potensi yang dapat dimanfaatkan adalah teknologi informasi. Perkembangan teknologi informasi saat ini membuat manusia sudah tidak lagi mempermasalahkan batas jarak, ruang dan waktu. Teknologi informasi melahirkan internet, internet menawarkan banyak manfaat bagi UKM untuk meningkatkan pemasaran produknya. Selain itu juga internet memberikan manfaat meningkatkan kesempatan UKM untuk bekerjasama dengan pengusaha lainya. Salah satu teknologi internet yang sedang berkembang pesat dan sangat berpotensi untuk mendorong pemasaran UKM adalah media sosial. Media sosial memiliki potensi menghubungkan banyak orang dengan mudah dan gratis.

Banyaknya manfaat penggunaan media sosial dalam mengembangkan UKM merupakan salah satu faktor pendorong yang kuat bagi UKM untuk terus memanfaatkan media sosial dalam rangka mengembangkan usahanya, meningkatkan penjualan produk, melakukan komunikasi dengan konsumen, serta mengembangkan jaringan pasar yang lebih luas lagi. hal ini senada dengan penelitian sebelumnya (Alam S.S.Noor, 2009), yang menunjukkan bahwa persepsi terhadap manfaat penggunaan teknologi informasi merupakan salah satu faktor pendorong bagi UKM untuk menggunakan media teknologi informasi.

Sosial media merupakan salah satu media yang mempermudah komunikasi interaktif antara pengusaha dengan siapapun, termasuk konsumen, dan berbagai pihak yang berkepentingan, kapanpun dan berada dimanapun. Sosial media sangat membantu sebagai penghubung 
informasi dan komunikasi dari produsen ke konsumen di manapun mereka berada dan berapapun jaraknya.

Media Sosial kini telah menjadi trend dalam komunikasi pemasaran. MenurutKaplan dan Haenlein (2010), media sosial adalah sekelompok aplikasi berbasiskaninternet yang dibangun berdasarkan kerangka pikiran ideologi dan teknologi dari Web2.0, dan memungkinkan terbentuknya kreasi pertukaran isi informasi dari pengguna internet. Web 2.0 adalah dasar terbentuknya sosial media (Carlsson, 2010). Contoh-contoh media sosial yang berkembang saat ini adalah : twitter, facebook, myspace,youtube, instagram, path, whatsapp, line, dll. Mengingat pentingnya informasi tentangbagaimana penggunaan media sosial bagi UKM dan manfaatnya, maka perlu dilakukan suatu penelitian observasional.

\section{Rumusan Masalah}

Berdasarkan latar belakang masalah di atas dapat dirumuskan masalah sebagai berikut:

1. Apakah pengaruh media sosial dan manfaatnya terhadap perkembangan Usaha Kecil Menengah (UKM)?

2. Bagaimana gambaran penggunaan media sosial pada Usaha Kecil Menengah (UKM)?

\section{Batasan Penelitian}

Agar penelitian tidak menyimpang dari masalah yang sudah dirumuskan, maka peneliti membatasi masalah yang dikaji dalam penelitian ini, adapun pembatasan masalah dalam penelitian ini adalah :

- Penelitian ini terbatas pada tiga jenis usaha jasa, dagang dan industri dan dibatasi pada lima bidang usaha yaitu makanan, event organizer, konveksi, kerajinan, dan transportasi.

- Jenis media sosial yang digunakan dibatasi pada media sosial facebook, blackberry messangger, WhatsApp, Instagram, Twitter, Line.

\section{Tujuan Penelitian}

Setiap penelitian yang akan dilakukan pasti ada tujuannya, begitupun dengan penelitian ini dilkakukan dengan beberapa tujuan. Adapun tujuan dari penelitian ini adalah :

1. Untuk mengetahui pengaruh implementasi media sosial terhadap perkembangan usaha kecil menengah (UKM).

2. Untuk mengetahui pengaruh media sosial terhadap peningkatan pemasaran usaha kecil menengah (UKM). 
3. Untuk mengetahui pengaruh media sosial terhadap peningkatan produktivitas usaha kecil menengah (UKM).

\section{B. STUDI LITERATURE C.METODE PENELITIAN \\ 1. Desain Penelitian dan Obyek Penelitian}

Penelitian ini merupakan penelitian deskriptif observasional pada Usaha Kecil Menengah (UKM) di wilayah Rantauprapat Kabupaten Labuhanbatu. Penelitian ini menggunakan metode wawancara terstruktur, wawancara mendalam dan observasi terhadap UKM dan media sosial yang digunakan. Obyek dalam penelitian ini adalah pemilik, pengelola dan karyawan UKM yang dipilih secara purpose sampling. Subyek dipilih sesuai dengan kriteria : 1. merupakan pemilik atau pengelola UKM, 2. merupakan karyawan UKM, 3. pernah menggunakan media sosial dalam komunikasi perusahaan, 3. bersedia menjadi Obyek penelitian.

\section{Metode Pengumpulan Data}

Penelitian ini menggunakan data primer yang diperoleh berdasarkan wawancara terstruktur dan wawancara mendalam kepada pemilik dan pengelola UKM. Data yang diperoleh meliputi data Ciri-ciri UKM, data penggunaan sosial media dalam perusahaan, termasuk tujuan, manfaat dan hambatan yang dihadapi. Data dilengkapi dengan hasil observasi peneliti terhadap UKM dan media sosial yang digunakan.

\section{Analisis Data}

Teknik analisis data yang digunakan dalam penelitian ini adalah Teknik analisis Regresi linier Berganda.

\section{HASIL DAN PEMBAHASAN}

1. Uji normalitas

b. Calculated from data.

Berdasarkan tabel di atas terlihat semua variable residual memiliki nilai signifikansi sebesar 0,908 yaitu lebih besar dari alpha $(0,908>0,05)$. Dengan demikian dapat dikatakan bahwa data hasil penelitian sudah berdistribui normal sehingga analisis regresi dapat dilaksanakan

\section{Uji Multikolinearitas}

Uji multikolinearitas digunakan untuk menguji adanya hubungan linear yang sempurna (mendekati sempurna) antara beberapa atau semua variabel bebas. 


\section{Tabel 2.}

\section{Uji Multikolinearitas}

\section{Coefficients $^{\mathbf{a}}$}

a. Dependent Variable: UKM

\begin{tabular}{|c|c|c|c|}
\hline \multirow[b]{2}{*}{ Model } & & \multicolumn{2}{|c|}{ Collinearity Statistics } \\
\hline & & Tolerance & VIF \\
\hline 1 & (Constant) & & \\
\hline & Media social & ,739 & 1,182 \\
\hline & Pemasaran & |,878 & $\mid 1,147$ \\
\hline & Produktivitas & 885 & 1,192 \\
\hline
\end{tabular}

Dari tabel uji multikolinearitas diketahui bahwa nilai tolerance media sosial yaitu $0,739>0,1$ maka tidak terjadi multikolinearitas , pemasaran yaitu $0,878>0,1$ maka tidak terjadi multikolinearitas dan produktivitas yaitu 0,885 > 0,1 maka tidak terjadi multikolinearitas.

Berdasarkan uji multikolinearitas diketahui bahwa nilai VIF dari media sosial yaitu $1,182<10$ maka tidak terjadi multikolinearitas, nilai VIF pemasaran yaitu 1,147 < 10 maka tidak terjadi multikolinearitas dan VIF produktivitas yaitu $1,192<10$ maka tidak terjadi multikolinearitas.

\section{Uji Heteroskedastisitas}

Uji heteroskedastisitas digunakan untuk mendeteksi apakah dalam model regresi terjadi ketidaksamaan varian dari residual satu pengamatan ke pengamatan lain.

\section{Tabel 3}

\section{Hasil Uji Heterokedastisitas}

\begin{tabular}{|l|l|l|l|l|}
\hline No & Variabel & Sig & Alpa & Keterangan \\
\hline 1 & Media Sosial & 0,561 & 0,05 & Tidak heteroskedastisitas \\
\hline 2 & Pemasaran & 0,452 & 0,05 & Tidak heteroskedastisitas \\
\hline 3 & Produktivitas & 0,514 & 0,05 & Tidak heteroskedastisitas \\
\hline
\end{tabular}

Sumber: data diolah,

Dari Tabel 3 terlihat bahwa tidak terjadi heteroskedastisitas karena nilai signifikan dari semua variabel bebas lebih besar dari alpha $(0,05)$. Dengan demikian analisis regresi dapat dilakukan karena tidak terjadi heteroskedastisitas

\section{Hasil Analisis Regresi Berganda}


Analisis ini digunakan untuk mengetahui pengaruh variabel bebas (media social, pemasaran dan produktivitas) terhadap variabel terikat (UKM). Hasil analisis regresi sebagai berikut:

\section{Tabel 4.}

\section{Hasil Analisis Regresi Linear Berganda}

\begin{tabular}{|c|c|c|c|c|c|c|}
\hline & & \multicolumn{5}{|c|}{ Coefficients $^{\mathrm{a}}$} \\
\hline . & & \multicolumn{2}{|c|}{$\begin{array}{l}\text { Unstandardized } \\
\text { Coefficients }\end{array}$} & $\begin{array}{l}\text { Standardized } \\
\text { Coefficients }\end{array}$ & & \\
\hline \multicolumn{2}{|l|}{ Model } & $B$ & Std. Error & Beta & $\mathrm{t}$ & Sig. \\
\hline 1 & (Constant) & 1,635 & 1,672 & & 1,438 &, 134 \\
\hline & Media sosial & ; 413 &, 047 & |,475 & 4,593 &, 001 \\
\hline & Pemasaran & 265 &, 051 &, 218 & 3,825 &, 000 \\
\hline & Produktivitas & I.314 & .063 & $\mid, 488$ & $\mid 5,721$ & $\mid, 000$ \\
\hline
\end{tabular}

a. Dependent Variable: UKM

Hasil pengolahan komputer dapat diketahui persamaan koefisien regresi linier berganda yang diperoleh sebagai berikut:

$Y=1,635+0,413 X_{1}+0,265 X_{2}+0,314 X_{3}$

\section{- Koefisien Determinasi $\left(\mathbf{R}^{2}\right)$}

Analisis ini digunakan untuk mengetahui seberapa besar sumbangan atau pengaruh yang diberikan variabel bebas terhadap variabel terikat yang ditunjukkan dengan persentase. Hasil koefisien determinasi sebagai berikut:

\section{Tabel 5}

\section{Hasil Koefisien Determinasi $\left(\mathbf{R}^{2}\right)$}

Model Summary ${ }^{\mathbf{b}}$

\begin{tabular}{|c|c|c|c|c|}
\hline Model & $\mathrm{R}$ & R Square & $\begin{array}{l}\text { Adjusted R } \\
\text { Square }\end{array}$ & $\begin{array}{l}\text { Std. Error of the } \\
\text { Estimate }\end{array}$ \\
\hline 1 &, $773^{\mathrm{a}}$ & ,637 &, 529 & 1,195 \\
\hline
\end{tabular}

a. Predictors: (Constant), Produktivitas, Pemasaran, Media social

b. Dependent Variable: UKM

Nilai koefisien determinasi $\left(\mathrm{R}^{2}\right)$ menunjukkan besarnya kontribusi pengaruh

variabel bebas terhadap variabel terikat. Hasil perhitungan yang dihasilkan pada tabel 5 diatas menunjukkan nilai $\mathrm{R}^{2}=0,637$. Hal ini berarti menunjukkan bahwa sebesar $63,70 \% \mathrm{UKM}$ dipengaruhi oleh media sosial, pemasaran dan produktivitas sedangkan sisanya sebesar $36,30 \%$ dipengaruhi oleh variabel lain yang tidak diteliti. 


\section{Pengujian Hipotesis}

Berdasarkan data penelitian yang dikumpul baik untuk variabel terikat (UKM) maupun variabel bebas (media sosial, pemasaran dan produktivitas) yang diolah dengan bantuan program spss versi 20.0 uji signifikan simultan (uji-f) dan uji signifikan parsial (uji-t) sebagai berikut:

\section{Uji Hipotesis Secara Parsial (Uji t)}

Analisis ini digunakan untuk mengetahui tingkat signifikansi pengaruh variabel bebas terhadap variabel terikat secara parsial. Hasil uji t sebagai berikut:

\section{Tabel 7}

\section{Hasil Uji t}

\begin{tabular}{|c|c|c|c|c|c|c|}
\hline & & \multicolumn{5}{|c|}{ Coefficients $\mathrm{s}^{\mathrm{a}}$} \\
\hline " & & \multicolumn{2}{|c|}{$\begin{array}{l}\text { Unstandardized } \\
\text { Coefficients }\end{array}$} & \multirow{2}{*}{$\begin{array}{l}\text { Standardized } \\
\text { Coefficients } \\
\text { Beta } \\
\end{array}$} & \multirow[b]{2}{*}{$\mathrm{t}$} & \multirow[b]{2}{*}{ Sig. } \\
\hline \multicolumn{2}{|l|}{ Model } & $B$ & Std. Error & & & \\
\hline 1 & (Constant) & 1,635 & 1,672 & & 1,438 & $\overline{134}$ \\
\hline & Media sosial & ;,413 & |,047 & |,475 & 4,593 &, 001 \\
\hline & Pemasaran & |,265 & $\mid, 051$ & |,218 & $\beta, 825$ & |,000 \\
\hline & Produktivitas & , 314 & ,063 & |,488 & 5,721 &, 000 \\
\hline
\end{tabular}

a. Dependent Variable: UKM

Sumber: Data diolah

Pengujian hipotesis media sosial ( $\left.\mathrm{X}_{1}\right)$ terhadap UKM (Y). Langkah-langkah pengujiannya sebagai berikut:

Menentukan hipotesis nihil (Ho) dan hipotesis alternatif (Ha).

Ho : $b_{1}=0$, Variabel media sosial tidak berpengaruh secara signifikan terhadap UKM di Rantauprapat.

tpe

Ha : $b_{1} \neq 0$, Variabel media sosial berpengaruh secara signifikan terhadap UKM di Rantauprapat b. Menentukan level of significance ( $\$ 0,05)$ 
$\mathrm{Df}=(/ 2 ; \mathrm{n}-1-\mathrm{k})$

$(0,05 / 2 ; 98-1-3) 0 ; 0$

1,665

$\mathrm{t}$ hitung $=4,593$

Kesimpulan

Hasil perhitungan diperoleh nilai t hitung $(4,593)>$ dari t tabel $(1,665)$ maka Ho ditolak dan Ha diterima, sehingga variabel media sosial berpengaruh secara signifikan terhadap UKM di Rantauprapat.

Pengujian hipotesis pemasaran $\left(\mathrm{X}_{2}\right)$ terhadap UKM (Y). Langkah-langkah pengujiannya sebagai berikut:

Menentukan hipotesis nihil (Ho) dan hipotesis alternatif (Ha).

Ho : $\mathrm{b}_{2}=0$, Variabel pemasaran tidak berpengaruh secara signifikan terhadap UKM di Rantauprapat.

Ha : $b_{2} \neq 0$,Variabel pemasaran berpengaruh seebra signifikan terhadap UKM di Rantauprapat. $2 \neq 1$ in

Menentukan level of significance $(=0,05) \underset{\text { tud }}{\mathrm{D}} \stackrel{\text { pal }}{=}(/ 2 ; \mathrm{n}-1-\mathrm{k})$

$(0,05 / 2 ; 98-1-3)(0), 0$

1,665

$\mathrm{t}$ hitung $=3,825$

Kesimpulan

Hasil perhitungan diperoleh nilai t hitung $(3,825)>$ dari t tabel $(1,665)$ maka Ho ditolak dan Ha diterima, sehingga variabel pemasaran berpengaruh secara signifikan terhadap UKM di Rantauprapat.

Pengujian hipotesis produktivitas $\left(\mathrm{X}_{3}\right)$ terhadap UKM (Y). Langkah-langkah pengujiannya sebagai berikut:

Menentukan hipotesis nihil (Ho) dan hipotesis alternatif (Ha).

Ho : $b_{2}=0$,Variabel produktivitas tidak berpengaruh secara signifikan terhadap UKM di Rantauprapat. 
Ha : $b_{2} \neq 0$,Variabel produktivitas berpengaruh secara signifikan terhadap UKM di Rantauprapat.

$2 \neq 1 \quad$ ita

Menentukan level of significance $(=0,05) \underset{\mathrm{tu}}{\mathrm{Df}} \underset{\alpha}{\overline{\mathrm{pal}}}(\mathrm{I} ; \mathrm{n}-1-\mathrm{k})$

$(0,05 / 2 ; 98-1-3)_{0,0}^{\alpha /,}$

1,665

$\mathrm{t}$ hitung $=5,721$

Kesimpulan

Hasil perhitungan diperoleh nilai t hitung $(5,721)>$ dari t tabel $(1,665)$ maka Ho ditolak dan Ha diterima, sehingga variabel produktivitas berpengaruh secara signifikan terhadap UKM di Rantauprapat. 


\section{Uji Hipotesis Secara Simultan (Uji F)}

Uji F digunakan untuk mengetahui signifikans pengaruh variabel bebas secara bersama-sama terhadap variabel terikat. Hasil uji F sebagai berikut:

\section{Tabel 8}

\section{Hasil Uji F}

\begin{tabular}{|c|c|c|c|c|c|c|}
\hline \multicolumn{7}{|c|}{ ANOVA $^{\mathbf{a}}$} \\
\hline Model & & $\begin{array}{l}\text { Sum of } \\
\text { Squares }\end{array}$ & Df & Mean Square & $\mathrm{F}$ & Sig. \\
\hline 1 & 'Regression & 155,874 & 3 & 51,958 & 36,281 &, $000^{\mathrm{b}}$ \\
\hline & Residual & 134,616 & 94 & 1,432 & & \\
\hline & Total & 290,490 & 97 & & & \\
\hline
\end{tabular}

a. Dependent Variable: UKM

b. Predictors: (Constant), Produktivitas, Pemasaran, Media social

Sumber: Data diolah

Langkah-langkah pengujiannya adalah:

a. Menentukan Ho dan Ha

Ho : b1, b2, = 0 Tidak ada pengaruh yang signifikan antara variabel media sosial, pemasaran dan produktivitas secara simultan terhadap UKM di

Rantauprapat.

ifik

Ha $: b_{1}, b_{2} \neq 0$ Ada pengaruh yang signifikan antara variabel media sosial, pemasaran dan produktivitas secara simultan terhadap UKM di Rantauprapat.

Menentukan level of significance $(=0,05) \mathrm{Df}=\mathrm{F} ;(\mathrm{k}):(\mathrm{n}-1-\mathrm{k})$

$(0,05) ;(3):(98-1-3)$

2,47

$\mathrm{F}_{\text {hitung }}=36,281$

Kesimpulan

Nilai F hitung $(36,281)>$ dari nilai $F$ tabel $(2,47)$ dengan nilai signifikan $0,000<0,05$ maka Ho ditolak sehingga ada pengaruh yang signifikan media sosial, pemasaran dan produktivitas secara simultan terhadap UKM di Rantauprapat. 


\section{H. Pembahasan}

\section{Pengaruh Media Sosial terhadap UKM di Rantauprapat}

Secara analisis deskriptif tentang media sosial pada UKM di Rantauprapat menunjukkan bahwa distribusi jawaban responden paling tinggi skornya adalah pada pernyataan Penggunaan media social facebook lebih baik dalam melakukan promosi dengan rata-rata skor 4,7. Responden yang menjawab setuju $28,6 \%$, responden yang menjawab sangat setuju sebanyak $68,4 \%$, dan responden yang menjawab kurang setuju sebanyak $3,1 \%$.

Sedangkan tanggapan responden yang memiliki rata-rata skor paling rendah adalah pada pernyataan Intensitas penggunaan media sosial dalam waktu satu bulan dengan rata-rata skor 4,2 , responden yang menjawab setuju $64,3 \%$, responden yang menjawab sangat setuju sebanyak $27,6 \%$, dan responden yang menjawab kurang setuju sebanyak $8,2 \%$.

Hasil pengujian koefisien media sosial terhadap UKM di Rantauprapat memiliki jalur positif sebesar 0,413 yang berarti semakin baik media sosial akan meningkatkan

UKM di Rantauprapat. Nilai probabilitas (p) sebesar 0,001 yang berarti ada pengaruh signifikan media sosial terhadap UKM di Rantauprapat.

\section{Pengaruh pemasaran terhadap UKM di Rantauprapat}

Secara analisis deskriptif tentang pemasaran pada UKM di Rantauprapat menunjukkan bahwa distribusi jawaban responden paling tinggi skornya adalah pada pernyataan rutinitas iklan pemasaran melalui media masa lebih baik dengan rata-rata skor 4,2. Responden yang menjawab sangat setuju 24,5\%, responden yang menjawab setuju sebanyak $69,4 \%$, dan responden yang menjawab kurang setuju sebanyak $6,1 \%$.

Sedangkan tanggapan responden yang memiliki rata-rata skor paling rendah adalah pada pernyataan kurang teliti dalam melakukan input harga ketika melakukan pemasaran dengan rata-rata skor 3,6, responden yang menjawab setuju $66,3 \%$, responden yang menjawab sangat setuju sebanyak 11,2\%, dan responden yang menjawab kurang setuju sebanyak 11,2\%.

Hasil pengujian koefisien pemasaran terhadap UKM di Rantauprapat memiliki jalur positif sebesar 0,265 yang berarti semakin baik pemasaran akan meningkatkan UKM di Rantauprapat. Nilai probabilitas (p) sebesar 0,000 yang berarti ada pengaruh signifikan pemasaran terhadap UKM di Rantauprapat. 


\section{Pengaruh produktivitas terhadap UKM di Rantauprapat}

Secara analisis deskriptif tentang produktivitas pada UKM di Rantauprapat menunjukkan bahwa distribusi jawaban responden paling tinggi skornya adalah pada pernyataan kualitas barang sangat menentukan produktivitas barang dengan rata-rata skor 4,5. Responden yang menjawab sangat setuju $51 \%$, responden yang menjawab setuju sebanyak $43,9 \%$, dan responden yang menjawab kurang setuju sebanyak $5,1 \%$.

Sedangkan tanggapan responden yang memiliki rata-rata skor paling rendah adalah pada pernyataan produktivitas mengalami masalah kekurangan bahan baku dengan rata-rata skor 4,1. Responden yang menjawab setuju 67,3\%, responden yang menjawab sangat setuju sebanyak $22,4 \%$, dan responden yang menjawab kurang setuju sebanyak $10,2 \%$.

Hasil pengujian koefisien produktivitas terhadap UKM di Rantauprapat memiliki jalur positif sebesar 0,314 yang berarti semakin baik produktivitas akan meningkatkan UKM di Rantauprapat. Nilai probabilitas (p) sebesar 0,000 yang berarti ada pengaruh signifikan produktivitas terhadap UKM di Rantauprapat.

\section{SIMPULAN DAN SARAN}

Penelitian ini menyimpulkan bahwa UKM yang di observasi telah menggunakan media sosial dalam perusahaannya. Media sosial yang paling banyak digunakan adalah Facebook, Twitter dan Instagram. Bagi sebagian besar UKM manfaat penggunaan media sosial adalah untuk komunikasi personal dengan konsumen, Pemasaarn dan iklan, mendata kebutuhan konsumen, memberikan respon pada konsumen, membantu pengambilan keputusan dan sebagai forum diskusi dengan konsumen. Berdasarkan penelitian penggunaan media sosial dapat meningkatkan penjualan hingga lebih dari $100 \%$ apabila perusahaann melakukan update informasi secara konsisten melalui media sosial setiap hari.

Pengusaha UKM perlu memanfaatkan media sosial secara optimal dan secara konsisten melakukan update informasi setiap hari untuk mengembangkan pangsa pasar dan meningkatkan penjualan produk. Perlu dilakukan penelitian lanjutan untuk

melakukan pengukuran peningkatan penjualan secara akurat sehingga analisa pengaruh penggunaan media sosial terhadap peningkatan penjualan bisa dilakukan lebih akurat. 


\section{DAFTAR PUSTAKA}

Alam, S.S., Noor, M.K.M., 2009. International Journal Of Business and Management. Jakarta: PT Raja Grafindo Persada

Carter, J., 2014. Social Media Strategies in Small Business. Manchester: Manchester Metropolitan University

Chaterina, Intan. 2012. The Effect Of Customer Engagement In The Social MediaTowards Trust (Study To Facebook Sunsilk Indonesia) (Skripsi,UniversitasIndonesia, 2013, diterbitkan )

Edomwan, S., Prakasan, S.K., Kouame, D., Watson, J., Seymour, T., 2011. The History of Social Media and Its Impact on Business. The Journal of Applied Managementand Entrepreneurship, 16 (3), pp. 1-13.

Evans, Dave. 2008. Social Media Marketing An Hour A Day. Canada: Wiley Publishing, Inc

Evans, Dave. 2010. Praise for Social Media Marketing: The Next Generation of Business

Engagement. Indianapolis: Wiley Publishing, Inc.

Fandy, Tjiptono. 2008. Strategi Pemasaran. Yogyakarta: PT ANDI Offset

Faraz Farooq, Zohaib Jan . 2012. The Impact of Social Networking to Influence Marketingthrough Product Reviews. Emerald Group Publishing Limited ISSN 2223-4985

Gurnelius, Susan. 2011. 30-minute Sosial Media Marketing. United States: McGraw-Hill Companies

Husein, Umar. 2000. Metodologi Penelitian, Aplikasi dalam Pemasaran. Jakarta: PT. Gramedia Pustaka Utama

Moch Hari Purwidiantoro, 2016. Pengaruh penggunaan media social terhadap usahakecil menengah (UKM). Jurnal EKA CIDA Vol. 1 No. 1 Maret 2016

Merril, T., Latham, K., Santalesa, R., Navetta, D., 2011. Social Media: The business benefit may be enermous, but can the risks-reputation, legal, operational-bemitigated? Information Law Group, Apr. p. 1-12.

Miller, R., Lammas, N., 2009. Social Media and its Implication for Viral Marketing. AsiaPacific Public Relation Journal, vol 11, pp. 1-9. 
Puntoadi, Danis. 2011. Meningkatkan penjualan melalui media sosial. Jakarta: PT. Gramedia Pustaka Utama.

Puntoadi,Danis. 2011. Menciptakan Penjualan Melalui Social Media, PT Elex Komputindo, Jakarta

Suharsimi, Arikunto. 2010. Prosedur Penelitian Suatu Pendekatan Praktik. Yogyakarta: Bina Aksara

Tuten, Tracy. 2008. Advertising 2.0: Social Media Marketing in a Web 2.0 World,Greenwood Publishing Group

Zarrella, Dan. 2010. The Social Media Marketing Book. Jakarta: PT. Serambi Ilmu Semesta 